\title{
Presentation by Janine Felson
}

\author{
Deputy Permanent Representative of Belize to the United Nations
}

In this paper, I will first address the role of the International Law Commission in the multilateral legislative process and then go on to discuss future challenges to the progressive development of international law and its codification.

Clarifying the role of the Commission in an increasingly democratized international legislative process is at the heart of the debate of the challenges it faces in achieving the objectives set forth in its statute. The statute entrusts the Commission with the promotion of the progressive development of international law and its codification. ${ }^{1}$ Scholars have debated the relevance in practice of a distinction between the progressive development of international law and its codification. That debate has provided varying perspectives of the role of the Commission.

For example, Alain Pellet has called the distinction "artificial"; while it was "intellectually attractive", the distinction has proved "practically impossible", according to Pellet. ${ }^{2}$ Speaking about the Commission's work, he stated that:

[a]ll topics involve partial codification since no topic is entirely new when it is undertaken by the [Commission] ... in addition, all imply an element of progressive development since, almost as a matter of definition, customary rules always comprise some elements of uncertainty calling for clarification and this is precisely one of the main purposes of codification. ${ }^{3}$

Pellet concluded that not only is progressive development "indissociable from codification", it is part of codification. ${ }^{4}$ The real question, he posits, should be "when is legal development 'progressive'?"5 In his view, the extent of what can

1 See article 1 of the ILC statute, UNGA Res 174 (II) (21 November 1947) as amended by UNGA Res 485(v) (12 December 1950); unga Res 984(X) (3 December 1955); Unga Res 985(X) (3 December 1955) and UNGA Res $36 / 39$ (18 November 1981). See also article 15 of the statute, which further clarifies the terms "codification" and "progressive development" of international law.

2 Alain Pellet, 'Responding to New Needs through Codification and Progressive Development' in Vera Gowlland-Debbas (ed), Multilateral Treaty-making: The Current Status of Challenges to and Reforms Needed in the International Legislative Process (Martinus Nijhoff 2000) 13, 15-16.

3 Ibid 15 .

4 Ibid 16.

5 Ibid 16. 
be determined "progressive development" is completing existing law, but not changing the entire system of the law of nations. In other words, the Commission decodes the logic of existing rules and uses that logic as the framework for developing them further.

To Pellet, members of the Commission serve strictly as "codifiers" addressing (in his words) "the real needs of the international society", that is to say, "the 'constitutional law' of the international society" which means "uniform legal rules which transversally cut through all fields covered by international law". 6 But if the members of the Commission were to be confined to the role of "codifiers" focused mainly on the global constitutive process, would codification itself be confined to a procedural function?

Husain Al-Baharna, has observed that the "distinction between 'development' and 'codification' has, unwittingly, been sidelined with dismal consequences". ${ }^{7}$ Al-Baharna argued for restoring the original intention of the drafters of the statute as regards the progressive development. In his view, the key to change was the realization of the object of the "promotion of development of international law". ${ }^{8}$ Could the "codifier" go beyond the clarification of customary international law to an active engagement in promoting its progressive development?

The dynamic nature of international relations and likewise of international law, which is further discussed below, could justify a more progressive role for the Commission. At the same time, the legitimacy of the Commission's work cannot be diminished. It is argued that the distinction between the progressive development and codification is important in determining what issues are more appropriate for experts, as opposed to issues that are more appropriate for intergovernmental negotiations. Herein the question of the form of the Commission's work takes on significance. In this regard, Sean Murphy has pointed out that

[a]n approach whereby the Commission blends codification with progressive development is defensible if the ultimate outcome is the adoption by States of a convention, but such blending in a situation where no further State action is envisaged, and with the expectation that the draft

6 Ibid 22.

7 Husain Al-Baharna, 'Future Topics for the Codification of International Law Viewed in Historical Perspective' in International Law on the Eve of the Twenty-first Century: Views from the International Law Commission (United Nations 1997) 379.

8 Ibid (emphasis added). 
articles will simply be seen as "the law", potentially casts the Commission in the role of legislator. ${ }^{9}$

David Caron suggested that the Commission's articles on the responsibility of States for internationally wrongful acts ${ }^{10}$ would have unwarranted influence primarily because of their form. ${ }^{11}$ Whether or not this is by design, the test of the influence of the Commission's work is whether States and other relevant actors determine that they offer appropriate and workable solutions. Accordingly, he argued that "the [Commission's] articles should exercise such influence as they deserve. But the question of how much influence they deserve requires an appreciation of their authority and a method for applying and interpreting them." In this regard, Caron touched upon the importance of considering the user of the Commission's work. This brings me to the question posed: To whom does the Commission speak?

While the Commission is accountable and reports to States, its audience is much wider than just States. Caron pointed out that even prior to their adoption by the Commission, the articles on State responsibility had already affected legal discourse, arbitral decisions, and possibly State practice. This point marks the end user of the Commission's work. The process of the development of international law involves a wide range of actors. Myres McDougal observed that, while the nation State through its officials remains the predominant decisionmaker, a vast proliferation of non-State entities perform important decision functions in what he coined the "global constitutive process". ${ }^{2}$ He spoke thus of international organizations serving both as participants and institutional structures for the interaction of other participants, including political parties, pressure groups, non-governmental organizations, multinational business entities, and even individuals as subjects of international law.

In light of this wider audience base, it is appropriate that the Commission has expressed a willingness not to restrict itself to traditional topics, but to consider those that reflect new developments in international law and pressing concerns of the international community as a whole. This willingness notwithstanding, the Commission's main criteria for the selection of new topics

Sean Murphy, 'Codification, Progressive Development, or Scholarly Analysis? The Art of Packaging the ILC's Work Product' in Maurizio Ragazzi (ed), Responsibility of International Organizations: Essays in Memory of Sir Ian Brownlie (Martinus Nijhoff 2013) 29, 35.

10 See Unga Res 56/83 (12 December 2001).

11 David D. Caron, 'The ILC Articles on State Responsibility: The Paradoxical Relationship between Form and Authority' (2002) 96 AJIL 857. 
should focus on the needs of States, on sufficiency and advancement of State practice, on feasibility and on concreteness.

Returning to an observation made by Al-Baharna in relation to the question of future topics, he noted that "the question of the selection of topics for codification and development of international law has not been an easy one" and that "it had become all the more daunting due to the vast changes in the socio-economic and political conditions of the world society."13 I would add to these changes (1) technological progress and invention, which have created a virtual world within which we conduct much of our day-to-day interactions; (2) growing influence of multinational entities, particularly over natural resources management; and (3) climate change and the Anthropocene, in particular the accelerated impacts of anthropogenic climate change, in the near term, for small island developing States (sIDs) and low-lying coastal States which is re-defining responsibilities for the protection of the environment. I would further propose that it is these very changes and the expanded range of participants in the contemporaneous global constitutive process that instructs a role for the Commission to go beyond the mere clarification of customary international law.

Accordingly, I would support entrusting the Commission with the promotion of the development of international law in those areas where the common concern of humankind is evident. Historically, the Commission has concluded work relating to the law of international responsibility and it is currently conducting work relating to the law of the environment. Therefore, it cannot be said that venturing into areas relating to the common concern of humankind would be revolutionary; it would be timely.

In the context of environmental law, the siDs have advocated for the development of international law in relation to the permanent loss and damage resulting from the adverse impacts of climate change, especially sea level rise. ${ }^{14}$ This issue has gained notoriety in the climate change context, particularly due to concerns regarding the implications for responsibility and liability. And yet it could be argued that, if the purpose of codification and the role of the codifiers is to address the needs of the international society and to instruct a societal order through institutions and law, then addressing the fundamental question

\footnotetext{
13 See Al-Baharna (n 7$) 373$.

14 See, inter alia, the statement of the Marshall Islands (on behalf of the Pacific Small Island Developing States), made in the Sixth Committee of the General Assembly under agenda item 81, 'Report of the International Law Commission on the work of its sixty-ninth session (Cluster II)' (26 October 2017) <https://papersmart.unmeetings.org/media2/ 16154559/marshall-islands-on-behalf-of-pacific-small-island-developing-states-.pdf>.
} 
of the territorial integrity of a State in the face of permanent loss and damage as a result of climate change is within the expectations and interests of all States, large and small.

This brings us full circle to the question regarding the distinction of the function of progressive development vs. codification. It is fair that, as Pellet observed, the two are indissociable, though as others suggest, this warrants some caution regarding how the Commission packages its work. Perhaps it is best to look beyond the bifurcation of the role of the Commission and instead to search for a practical functionality of the Commission as a progressive codifier, preserving its legitimacy and simultaneously promoting the development of international law. And perhaps, rather than debating the boundaries that the concepts of progressive development and codification could place on the Commission, we should rather reinforce the role of the Commission in relation to the utility of its work and its contribution to what Prof. Nico Schrijver elucidated in his keynote address, that is, the preservation of the rule of law in global affairs. ${ }^{15}$

15 See the keynote address by Nico Schrijver in Section 8 of this book. 